\title{
The One and the Many: Revisioning Adorno's Critique of Western Reason
}

\section{by Deborah Cook}

\section{First published in Studies in Social and Political Thought 18, 2010.}

The problem of the One and the Many has a long history; it can be traced all the way back to the pre-Socratic philosophers who were seeking a single principle that underlies reality. Even Heraclitus, who is perhaps better known for the view that nothing remains the same, postulated the fundamental unity of things. In one of the remaining fragments of his thought (Fragment 50), Heraclitus urged: 'It is wise to hearken, not to me, but to my Word, and to confess that all things are one.' Unity is alleged to be real; all things are one in an ontological sense. Nor does unity exclude diversity. For Heraclitus, 'it is essential to the being and existence of the One that it should be one and many at the same time, that it should be Identity in Difference' (Copleston, 1962: 56-57). Of course, Parmenides placed even greater emphasis on unity. Consigning difference or otherness to the realm of non-being, Parmenides asserted that Being alone - the One - exists.

Jürgen Habermas offers an important psychological gloss on this perennial theme of the One and the Many in his essay 'The Unity of Reason and the Diversity of its Voices.' Here, he remarks, in an explicitly Adornian vein, that with his abstract conception of a 'universal, eternal, and necessary being,' Parmenides tried to break the 'spell of mythological powers and the enchantment of demons.' With Parmenides, the 'fear of uncontrolled dangers that displayed itself in myths and magical practices now lodges within the controlling concepts of metaphysics itself.' The dangers that the notion of Being was supposed to avert also expressed themselves in 'deep-seated fears of death and frailty, of isolation and separation, of opposition and contradiction, of surprise and novelty.' By reducing the Many to 'mere images' of the One, Parmenides not only demoted diverse particulars to the realm of mere appearance, he made them reassuringly 'univocal, the surveyable parts of a harmonic order' (Habermas, 1992: 120).

Three problems beset this conception of the unity of all things. First, how can the One be everything if the universe is composed of many different things? Second, how can we do justice to the uniqueness and individuality 
of things if all is ultimately One? And third, how should matter be conceived? (ibid.: 121-123). While the first two questions interested Theodor Adorno, the third question about matter preoccupied Friedrich Schelling. But Habermas also thinks that Schelling marked a breakthrough in the conception of the One, Being, or unity. If the unity of all things was regarded for millennia as an ontological postulate, Schelling broke with this tradition when he denied that the 'unity of the many' is 'an objective whole prior to the human mind.' Rather than existing objectively, unity is 'the result of a synthesis executed by the mind itself.' In fact, Habermas alleges that Schelling revolutionized 'the basic concepts of metaphysics.' When he stated that reason is the sole 'source of world-constituting ideas,' and that 'history is the medium through which mind carries out its synthesis,' Schelling formulated problems that would eventually 'set postmetaphysical thinking in motion' (ibid.: 124).

For his part, however, Adorno charges that Schelling succumbed to identity-thinking. Yet, he follows Schelling to the extent that he also views the postulate of unity as a function of thought. In thought, we strive compulsively to range particular things under abstract universals, even as we confront a world that literally teems with individuated things. Disregarding the concrete singularity of things, thought, in its abstract generality, is animated by a unifying, totalizing impulse: it attempts - as Friedrich Nietzsche once put it - 'to make all being thinkable' by forcing things to 'yield and bend' under the yoke of abstraction (Nietzsche, 1982: 225). By pressing natural things into the mould of universal laws and totalizing conceptual schema, we reassure ourselves that all is one, that unity triumphs over diversity, that there is nothing new under the sun.

When he criticizes the unifying impetus of thought, Adorno also asks why unity has superseded diversity. He raises this question in his lectures on the Critique of Pure Reason when he observes that, for Kant, the concept of unity is 'the canon by which everything else can be judged.' The idea that the one has 'primacy over the many' is the unquestioned 'metaphysical premise' that Kant shared with 'the Enlightenment in the broadest sense, as ... with early Greek thought and with Christianity in its entirety.' Moreover, this premiss is not 'a mere homogenization that results from depriving a mass of diverse varied things of their differentiating features, while retaining the one thing they have in common.' Rather, this premiss is modelled after the unity of consciousness itself. As a result, the emphasis on unity at the expense of diversity is not 'so much the product of knowledge, as its essence' (Adorno, 2001: 196-197).

In a psychological explanation for the primacy of the One over the Many, Adorno argues that the primacy of the One or unity can be traced 
back to human prehistory when reason and its agent, the ego, emerged during the transition from magic to myth. Reason served as a means to the end that all human beings seek: self-preservation. In this respect, reason can be compared to the teeth on a bear since both 'serve the same purpose.' Reason is just a more effective instrument of adaptation to the natural world because it has made us 'animals with more far-reaching powers' (Adorno and Horkheimer, 1972: 222-223; 2002: 184-185). To survive, we began to subdue fearsome nature in thought by identifying natural things with our concepts of them in order to predict and control them. This subsumptive mode of thought persists today. Calling this offshoot of our own natural history 'identity-thinking,' Adorno often complained that the persistence of identity-thinking shows that human beings 'are still imprisoned in the natural context,' even and especially as organisms that assert themselves 'against the organic' (Adorno and Horkheimer, 1972: 54; 2002: 42). 'In fear,' Adorno wrote, our 'bondage to nature is perpetuated by a thinking that identifies, that equalizes everything unequal' (1973: 172).

Given thought's propensity to subordinate the Many under the One, Adorno wants philosophy to think critically about substituting unity for diversity, simplicity for complexity, permanence for change, and identity for difference. For the cognitive ascent from particular things to unifying concepts, principles and laws obscures the differences between things; it fails to do justice to their 'qualitative moments.' Now that reason has been equated 'more mathematico with the faculty of quantification,' it has also become 'weakened and at odds with itself' because quantification actually presupposes the 'ability to discriminate.' In the absence of the ability to make qualitative distinctions between things, 'the synthetic function of thought abstract unification - would not be possible' (Adorno, 1973: 43).

Since our ability to perceive difference, dissimilarity, has atrophied, reason is now 'pathic' (ibid.: 172). To cure us of this pathic form of reason, however, Adorno neither abandons reason nor dispenses with concepts. Instead, he insists that reason alone is the 'organon' of progress. Praising Kant for preserving the unity of reason, Adorno argues that 'a naturedominating and a reconciling level do not exist separate and disjunct within reason, rather both share all its determinations.' Nature-dominating reason can invert 'into its other' by reflecting critically on itself, by applying reason to itself in such a way that, 'in its self-restriction,' it finally 'emancipates itself from the demon of identity' (Adorno, 1998a: 152). In fact, Adorno's alternative cognitive paradigm, nonidentity thinking, involves this 'selfreflection of the concept.' Such thinking tries to penetrate 'the wall that the concept erects around itself and its concerns by virtue of its own conceptual nature' (Adorno, 2008: 62-63) in order to reveal the lack of identity between 
concepts and objects even as it discloses their affinity, or the embeddedness of concepts in the material world (Adorno, 1973: 12).

With nonidentity thinking, Adorno attempts to address the cognitive dimension of the problem of the One and the Many. However, this problem has a social dimension as well: can society accommodate itself to the diverse individuals who comprise it? In fact, the two dimensions of this problem are linked because late capitalist society and identity-thinking are 'akin' (verschwistert) (ibid.: 316). Where identity-thinking compulsively subsumes objects under concepts, late capitalist society reifies individuals, expunging their idiosyncrasies by subsuming them under abstract exchange relations. Like identity-thinking, which ignores the particularity of things, treating them as mere instances of more general kinds, exchange relations make 'nonidentical individuals and performances become commensurable and identical' (ibid.: 146). Adorno explains why identity-thinking and exchange are 'akin' when he examines the claim that 'knowledge really just repeats what has always existed in the actual process of human labour.' Here, he agrees with Marx: 'when consciousness reflects upon itself, it necessarily arrives at a concept of rationality that corresponds to the rationality of the labour process' (Adorno, 2001: 172).

Frequently referring to society as the 'universal,' Adorno stressed its virtually irresistible power over individuals. Over the course of history, the 'real total movement of society' - in the form of increasingly abstract exchange relations - became independent of the living individuals who created it and continue to sustain it. These relations now operate over their 'heads and through their heads' and are therefore 'antagonistic from the outset' (Adorno, 1973: 304). Today, individuals are not 'just character masks, agents of exchange in a supposedly separate economic sphere' because exchange relations have become so widespread, affecting so much of human life that, even where individuals 'think they have escaped the primacy of economics - all the way into their psychology, the maison tolérée of uncomprehended individuality - they react under the compulsion of the universal' (ibid.: 311). Since individuals are now mere appendages of society, 'the One takes precedence as the identity of the system that leaves nothing at large' (ibid.: 315).

Adorno emphasizes the gravity of our predicament when he declares that the primacy of volatile economic forces over individuals 'has its vanishing point in the death of all' (ibid.: 320). We may well end by annihilating all life on this planet because late capitalism now shackles us to the pursuit of our own individual survival as bearers of exchange relations; it obliges us to focus exclusively on our egocentric interests all the better to advance its own (ibid.: 343). But the death of all will have a related cause. 
For our survival also depends on the continued viability of the natural world. Like the individual, however, nature too is moribund. As Samuel Beckett foresaw in Endgame, we now face a catastrophic situation in which 'there's no more nature' (Beckett, 1958: 10). Commenting on Beckett's play, Adorno states that 'the complete reification of the world ... is indistinguishable from an additional catastrophic event caused by human beings, in which nature has been wiped out and after which nothing grows any more' (1991: 245).

By turning individuals into lifeless objects of exchange, reification is already tantamount to 'permanent death' (Adorno, 1973: 370). In turn, however, the moribund individual reduces nature to 'a residual caput mortuum' (Adorno, 2006: 151). We ensure our own survival by destroying the natural world on which our very lives depend. Echoing social ecologist Murray Bookchin - who rails against our death-oriented society - and ecofeminist Carolyn Merchant - who charts the course of the 'death of nature' - Adorno is concerned that the primacy of the capitalist process of production will result in the extinction of all living things because it forces us to disregard the more rational interests of our species. In Negative Dialectics, he speaks of 'a universal feeling, a universal fear, that our progress in controlling nature may ... help to weave the very catastrophe from which it was supposed to protect us' (Adorno, 1973: 67).

However, Adorno also believes that prospects for emancipation remain open. Freedom 'has always been possible, ... it has been possible at every moment' (2006: 181). For Adorno, moreover, freedom depends, at least in part, on recognizing our own affinity with nature. He imbues the Socratic maxim, 'Know Thyself,' with psychological, social and moral force when he asserts that one of the keys to initiating transformative change is critical selfawareness. Rational insight into our own natural history 'is the point of a dialectics of enlightenment' (Adorno, 1973: 270). In Negative Dialectics, Adorno revives the central thesis he and Horkheimer put forward in Dialectic of Enlightenment, namely, that a thorough critique of our instinctually driven subjugation of nature may 'prepare the way for a positive notion of enlightenment which will release it from entanglement in blind domination' (1972: xvi; 2002: xviii). Enlightenment requires that we acknowledge that our unceasing attempts to dominate nature, which account for the rise and fall of entire civilizations, were impelled by nature itself in the form of the instinct for self-preservation. An outgrowth of its natural drives, the mind is 'not what it enthrones itself as, the Other, the transcendent in its purity, but rather is also a piece of natural history' (Adorno, 1998a: 156).

At the same time, however, it is important to note that our affinity with nature does not mean that we are identical with it. Adorno develops a nonreductive and non-dualistic conception of humanity's natural history 
(see O'Connor, 2004: 97-98). To be sure, reason grew out of instinct: we acquired our capacity to abstract from nature owing to our affinity with nature when we opposed ourselves to nature in the struggle for survival. Nature itself - in the form of the instinct for self-preservation - called 'for something more than conditioned reflexes' (Adorno, 1973: 217). But Adorno also insists that what communicates through affinity must be differentiated from what it resembles. The affinity between mind and nature should not be understood as positive; it does not authorize a foundational conception of nature because the human mind partially extricated itself from nature in its attempts to dominate it. The mind became 'something else,' something other than instinct, by virtue of 'reflecting existence' with a view to ensuring its survival (Adorno, 1974: 243). Consequently, reflection on nature in ourselves involves both acknowledging our resemblance to nature as instinctual, embodied beings, and respecting nature's heterogeneity.

In an argument that may initially appear contradictory, Adorno states that 'we are no longer simply a piece of nature' only 'from the moment that we recognize that we are a piece of nature' (2000: 103, my emphasis). The mark of an enlightened mind, sustained mindfulness of nature in ourselves is the one capacity that actually does distinguish us from non-human nature. Although we continue to behave like other animals to the extent that survival instincts motivate our behaviour, we can deliberately change this behaviour because we have acquired the, as yet only partially developed, capacity to differentiate ourselves from nature by becoming more fully aware of our own entwinement in it. This is why Adorno considers mindfulness of nature to be one of the harbingers of freedom: freedom depends on 'nature becoming conscious of itself' (ibid.: 104).

This critical self-awareness holds out the prospect of leading more autonomous - more fully human - lives because it may eventually free us 'from the blind pursuit of natural ends,' and free us for 'alternative actions' (Adorno, 2000: 104). Reflecting on our own natural history, we may eventually transform self-preservation by redirecting this instinct towards more rational ends. In fact, Adorno asserts that reason should retain and strengthen its links with self-preservation because our behaviour can be deemed rational only 'in so far as it serves the principle that has been regarded ... as the true fundamental principle of every existent being: [suum] esse conservare, self-preservation' (ibid.: 137). As David Kaufmann also remarks, it is not self-preservation per se, but the 'limited rationality of selfpreservation ... that leads to the irrationality of a reason devoted entirely to means, to how things should be done rather than to what should be done' (2004: 175).

Since reason can rise above nature only by reflecting on its own 
instinctual basis in self-preservation, individuals must first improve their capacity for self-reflection (Adorno, 1998b: 273). In fact, Adorno declared in 'Education after Auschwitz' that the 'only education that has any sense at all is education toward critical self-reflection' (1998c: 193). But sustained and critical self-reflection would also reveal that our individual survival depends upon orienting the instinct for self-preservation towards the goal it implicitly contains, namely, the preservation of the species as a whole. Citing Max Weber, Adorno declares that, once it emancipates itself from 'the contingency of individually posed ends,' the 'subject of ratio, pursuing its selfpreservation, is itself an actual universal, society - in its full logic, humanity.' For Adorno, moreover, the 'preservation of humanity' is 'inexorably inscribed within the meaning of rationality.' Emphatically conceived, reason 'should not be anything less than self-preservation, namely that of the species, upon which the survival of each individual literally depends' (ibid.: 272-273).

We must abandon that stubborn attachment to our egocentric interests which is fostered under late capitalism because this attachment has become, not just destructive of nature, but self-destructive. Paradoxically, perhaps, it is no longer in our interest to be self-interested. Our interest in our own survival would be better served if we were to embrace the needs of all members of our species. Adorno is not reviving the crude rhetoric of selfsacrifice here. Instead, he endorses the goal that every rational human being seeks: self-preservation. Rather, he believes that the survival of individuals - not to speak of their flourishing as individuals - requires that they develop a far more profound sense of solidarity with all other individuals on this planet. Our survival depends upon sympathy with the human, with embodied and finite individuals who are all too vulnerable to pain and suffering. Adorno even sounds a Hegelian note when he states that the fixation of one's own need and one's own longing mars the idea of a happiness that will not arise until the category of the individual ceases to be self-seclusive' (1973: 352).

Still, Adorno also warns against hypostatizing the species for reasons that echo his concerns about the plight of individuals under late capitalism. On the one hand, it is 'part of the logic of the self-preservation of the individual that it should ... embrace ... the preservation of the species.' On the other hand, the 'embrace' of the species is problematic because 'there is an intrinsic temptation for this universality to emancipate itself from the individuals it comprises.' Even on the condition that 'species reason' is liberated 'from the particularity of obdurate particular interest,' the species may subsequently 'fail to free itself from the no less obdurate particular interest of the totality.' Since this 'conundrum' concerning the relationship 
between the individual and the species has not yet been resolved, Adorno considers it to be 'a problem of the greatest possible gravity' (2006: 44-45).

Adorno also argues that the preservation of humanity requires the transformation of society: self-preservation has its end in 'a reasonable organization of society' (1998b: 272). In fact, Adorno claims that late capitalist society is irrational because it continues to increase 'all apparatuses and means of quantifiable domination at the cost of the goal, the rational organization of humankind' (1998d: 138, translation modified). Here, the pressure of negativity, of damaged life, makes itself felt: the prospect of establishing humanity as the subject of its own history has really opened up only 'in the face of its extinction' (1998a: 145). Since late capitalism now threatens to destroy all life on earth, we are compelled to think about how society might be rationally organized to ensure the preservation of all nature, including ourselves. Progress is dialectical because 'historical setbacks, which themselves are instigated by the principle of progress ... also provide the condition needed for humanity to find the means to avert them in the future' (1998a: 154).

Adorno often described human beings as prisoners. Progress depends upon breaking out of the prison of survival instincts (Adorno, 1973: 180) and the subjective prison of identity-thinking (ibid.: 172). But it also requires that we break out of the 'objective context of delusion' that identitarian exchange relations promote because this context serves as 'the authority for a doctrine of adjustment' (ibid.: 148). Once we have burst out of the prison of cognition, concepts would reach beyond themselves to apprehend the qualitative differences that distinguish natural things qua particular, 'dereifying the ability to discriminate, the ability without which reason cannot exist' (Horowitz, 2007: 212). And, once we have escaped from the prison of survival instincts by acknowledging our own affinity with the natural world, and reflecting on nature in ourselves, we may finally establish freer intercourse between mind and body, ego and instinct. This awareness of ourselves as inextricably entwined with nature would also encourage us to put an end to our destructive and self-destructive behaviour by improving the metabolism between ourselves and non-human nature.

Finally, to break out of the delusive context that exchange relations promote when they treat all things as identical or One, we must abolish the 'vicious system of compensatory exchange' (Adorno, 1973: 299). Exchange relations must make good on the promise that is contained in the very idea of an exchange of equivalents; they can be made more rational by satisfying the more emphatic notion of 'free and just exchange' (ibid.: 147). For Adorno, progress is not 'merely an Other in relation to exchange, but rather exchange that has been brought to itself' (1998a: 159). A society in which exchange 
were truly free and just would ultimately transcend exchange because no part of workers' labour would be withheld from them (ibid.). No longer the mere pawns of exchange, individuals would also shape the social institutions and practices that in turn shape them. In their social relations, they would learn to respect and appreciate difference, not primarily in the generic straitjackets of age, sex, and race, but in the form of the diverse, the many, the diffuse and ambiguous (Adorno, 2001: 196). Social solidarity would be transformed. New forms of solidarity would emerge that permit differences between individuals to flourish even as they pursue common goals. In short, reconciliation, or the communication between what has been differentiated (Adorno, 1998e: 247) - nature, society, and human and non-human particulars - would 'release the nonidentical.' It would disclose the 'multiplicity of different things' (Adorno, 1973: 6) by substituting 'for the principle of unity and the primacy of the superordinated concept the idea of what would lie outside the spell of such unity' (ibid.: xx). Adorno aims to foster reconciliation by overcoming the tyranny of the One to reveal the infinite profusion of the Many.

Deborah Cook is Professor of Philosophy at the University of Windsor. She has published more than thirty articles on Adorno along with several books including The Culture Industry Revisited (1996), Adorno, Habermas and the Search for a Rational Society (2004), and Adorno on Nature (2011). Currently she is completing The Critical Matrix, a book on Adorno and Foucault.

\section{Bibliography}

Adorno, T. W. (1973) Negative Dialectics (trans. E. B. Ashton) New York: Continuum

Adorno, T. W. (1974) Minima Moralia: Reflections from Damaged Life (trans. E. F. N. Jephcott) London: New Left Books

Adorno, T. W. (1991) 'Trying to Understand Endgame' in Notes to Literature (Volume 1) (trans. S. Weber Nicholsen) New York: Columbia University Press

Adorno, T. W. (1998a) 'Progress' in H. Pickford (ed.) Critical Models: Interventions and Catchwords New York: Columbia University Press 
Adorno, T. W. (1998b) 'Marginalia to Theory and Praxis' in H. Pickford (ed.) Critical Models: Interventions and Catchwords New York: Columbia University Press

Adorno, T. W. (1998c) 'Education after Auschwitz' in H. Pickford (ed.) Critical Models: Interventions and Catchwords New York: Columbia University Press

Adorno, T. W. (1998d) 'Reason and Revelation' in H. Pickford (ed.) Critical Models: Interventions and Catchwords New York: Columbia University Press

Adorno, T. W. (1998e) 'On Subject and Object' in H. Pickford (ed.) Critical Models: Interventions and Catchwords New York: Columbia University Press

Adorno, T. W. (2000) Problems of Moral Philosophy (trans. R. Livingstone) Stanford: Stanford University Press

Adorno, T. W. (2001) Kant's Critique of Pure Reason (trans. R. Livingstone) Stanford: Stanford University Press

Adorno, T. W. (2006) History and Freedom: Lectures 1964-1965 (trans. R. Livingstone) Cambridge: Polity Press

Adorno, T. W. (2008) Lectures on Negative Dialectics: Fragments of a Lecture Course 1965/1966 (trans. R. Livingstone) Cambridge: Polity Press

Adorno, T. W. \& Horkheimer, M. (1972) Dialectic of Enlightenment (trans. J. Cumming) New York: Continuum

Adorno, T. W. \& Horkheimer, M. (2002) Dialectic of Enlightenment: Philosophical Fragments (trans. E. Jephcott) Stanford: Stanford University Press

Beckett, S. (1958) Endgame: A Play in One Act London: Faber and Faber

Copleston, F. (1962) A History of Philosophy (Volume 1): Greece and Rome (Part 1) New York: Doubleday \& Company Inc.

Habermas, J. (1992) 'The Unity of Reason in the Diversity of its Voices' Postmetaphysical Thinking: Philosophical Essays (trans. W. M. Hohengarten) Massachusetts: MIT Press 
Horowitz, A. (2007) 'Mystical Kernels? Rational Shells? Habermas and Adorno on Reification and Re-enchantment' in D. A. Burke, C. J. Campbell, K. Kiloh, M. K. Palamarek \& J. Short (eds.) Adorno and the Need in Thinking: New Critical Essays Toronto: The University of Toronto Press

Kaufmann, D. (2004) 'Correlations, Constellations, and the Truth: Adorno's Ontology of Redemption' in G. Delanty (ed.) Theodor W. Adorno (Volume 1): Philosophy, Ethics and Critical Theory London: Sage

Nietzsche, F. (1982) 'Thus Spoke Zarathustra' in W. Kaufmann (ed.) The Portable Nietzsche New York: Penguin Books

O'Connor, B. (2004) Adorno's Negative Dialectic: Philosophy and the Possibility of Critical Rationality Massachusetts: MIT Press 